\title{
Tree and Tundra Cover Anomalies in the Subarctic Forest-Tundra of Northwestern Canada
}

\author{
KEVIN TIMONEY ${ }^{1}$
}

(Received 7 January 1992; accepted in revised form 19 October 1994)

\begin{abstract}
Factors that may account for subarctic vegetation patterns that are not reconcilable with synoptic climate were sought by reference to data on local climate, soils, parent materials, vegetation, and topography. Where the forest-tundra lies climatically northward, the vegetation transition zone is relatively narrow, and the soils are nutrient-rich, fine-textured loamy Cryosols derived from sedimentary rocks. Where the forest-tundra lies south of its climatic potential, the zone is wide, and the soils are relatively dry, nutrient-poor loamy sand and sandy loam Brunisols derived from crystalline rocks. Seven regional anomalies in landscape cover of tree and upland tundra vegetation are discussed with reference to topoclimate, edaphic controls, and bioclimatic feedback. Prominent anomalies include the Thelon River tree oasis, the great breadth of the southeastern foresttundra, and the southward plunge of the forest-tundra north of Great Slave Lake. Elevation differences as small as $50 \mathrm{~m}$ are shown to affect tree cover.
\end{abstract}

Key words: bioclimate, edaphic, fire, spruce, topoclimate, tree line, tundra

RÉSUMÉ. On a recherché les facteurs pouvant expliquer les schémas de végétation subarctique qui sont inexplicables par le climat synoptique, en se référant aux données sur le climat, les sols, les matériaux d'origine, la végétation et la topographie des lieux. Là où la toundra boisée est plus septentrionale que ne l'indique le climat, la zone de transition de la végétation est relativement étroite, et les sols sont des gélisols limoneux à texture fine, riches en éléments nutritifs, dérivés des roches sédimentaires. Là où la toundra boisée s'étend au sud de son potentiel climatique, la zone est large, et les sols sont des brunisols relativement secs de sable loameux et de loam sableux pauvres en éléments nutritifs, dérivés de roches cristallines. On discute sept anomalies régionales dans le couvert d'arbres et dans la végétation de toundra de haute-terre, en se référant au topo-climat, aux facteurs édaphiques et à la rétroaction bioclimatique. Les anomalies les plus visibles comprennent les bocages de la rivière Thelon, la grande étendue de la toundra boisée du sud-est et la descente vers le sud de la toundra boisée, au nord du Grand Lac de l'Esclave. On montre que des différences de niveau aussi faibles que $50 \mathrm{~m}$ affectent le couvert d'arbres.

Mots clés: bioclimat, édaphique, feu, épinette, topo-climat, ligne des arbres, toundra

Traduit pour la revue Arctic par Nésida Loyer.

\section{INTRODUCTION}

Large and relatively uniform life zones or biomes correspond to particular climates and soils. Within a biome, similar vegetation and successional trends will be found on particular suites of soils, parent materials, and landforms. This approach forms the basis of ecological land classification in Canada. The areally dominant vegetation and soils that characterize average conditions within a biome are known as zonal types. Zonal or "normal" sites are characterized by deep loamy soils, moderate levels of soil nutrients, and welldrained positions neither protected from nor exposed to climatic extremes (Ecoregions Working Group, 1989).

Within the high subarctic of northwestern Canada, zonal vegetation is open crown conifer forests, dwarf shrub tundras, and forest-tundras (single-stemmed and clonal spruce and larch in a tundra matrix), and zonal soils are Cryosols and Brunisols. The forest-tundra of the northwest, dominated by white spruce (Picea glauca [Moench] Voss), is significantly narrower and extends climatically farther north than the forest-tundra of the southeast, dominated by black spruce (Picea mariana [Mill.] BSP.) (Timoney et al., 1992, 1993a).

In the central Northwest Territories, the forest tundra plunges southward, both in latitude and climatically, at a major landscape transition from nutrient-rich loamy Cryosols over sedimentary rocks in the northwest to nutrient-poor sandy Brunisols over crystalline rocks on the Shield. Relative to the southeast, northwestern soils are finer in texture (silt loam to clay loam) and significantly higher in cation exchange capacity, nitrogen, potassium, calcium, magnesium, and organic carbon (Timoney et al., 1993a). Forest-tundra vegetation and species composition in northwestern Canada show strong correlations with soil $\mathrm{pH}$, texture, moisture, and latitude (Robinson et al., 1989; Timoney et al., 1993a).

Edaphic control is second only to climate in shaping the areal pattern of vegetation (Cain, 1944), and is understandable in the context of the "law of the minimum." First described by von Liebig in 1840, the law might be stated as:

${ }^{1}$ Treeline Ecological Research, Box 1118, Ft. Smith, Northwest Territories X0E 0P0, Canada

(C) The Arctic Institute of North America 
"the growth and/or distribution of a species is dependent on the one environmental factor most critically in demand" (Barbour et al., 1980:28; see also Fritts, 1971:424-427). There are important modifications to the law of the minimum. Environmental factors act mutually as a concerted force (Cain, 1944); a low level of one factor can sometimes be compensated for by optimum levels of other factors, and the effects of one factor can be magnified as other factors reach maximum or minimum values (Barbour et al., 1980).

Because zonal vegetation is not subjected to extremes of climate or soil conditions, gradients in percent cover of subarctic tree and tundra vegetation generally correspond to synoptic climatic gradients, and assume the form of a sigmoid wave (Timoney et al., 1992, 1993b). In areas where vegetation seems to correspond poorly with synoptic climate, factors such as topography and vegetation may act to produce local climatic effects. Summer temperatures of slope bases and valleys are on average colder than those of hilltops and flat terrain (Dolgin, 1970; Huovila, 1970). Climatic differences, e.g., between adjacent open and closed crown forest, or between north- and south-facing slopes, can be equivalent to tens or hundreds of $\mathrm{km}$ of macroclimatic gradient (F.K. Hare, pers. comm. 1988).

Vegetation cover anomalies fall into two categories: 1) cardinal anomalies, where a region of the forest-tundra is located farther south or north than climate would suggest or where the forest-tundra is wider or narrower than normal in comparison to corresponding climatic gradients; and 2) regional anomalies, where areas of high cover of trees or tundra do not correspond to synoptic climate. Anomalies may be related to factors such as topoclimate, edaphic controls, bioclimatic feedback, and fire.

The purpose of this paper is to identify and describe zonal vegetation cover anomalies in the forest-tundra of northwestern Canada and to identify factors that may account for these anomalies.

\section{STUDY REGION}

The study region extends across the subarctic of northwestern Canada from the Yukon border to the west coast of Hudson Bay (Fig. 1). The vegetation, climate, and terrain of the study region are described by Timoney et al. (1992, 1993a, b). Within the study region, "northwest" refers to that area extending from the Yukon border SE to the Coppermine River. The "southeast" extends from south of the Coppermine River to the west coast of Hudson Bay.

\section{METHODS}

Field and laboratory methods are described by Timoney et al. (1992,1993a). In essence, a matrix of 1:50 000 to 1:70 000 scale airphotos was analyzed at $6 \times$ magnification for percent cover of tree, upland tundra, tall shrub, treeless wetland, burned forest, semi-barren bedrock, eroding terrain, and water. Mean, minimum, and maximum elevations, parent materials, and surficial features were recorded. Field sampling, supplemented by literature, was used to ground truth the interpretations. Cover isoline maps for the various vegetation types were produced (using Sampson, 1978); geographic accuracy, as determined by ground truth and unaveraged airphoto data, was found to be $\pm 15 \mathrm{~km}$.

Tree and tundra cover anomalies were identified as areas where peaks or depressions in cover could not be explained by synoptic climate, mountains, or hills. Anomalies were quantified by determining percent tree cover in the anomaly core area, and comparing these figures to regional tree cover isolines outside the anomaly. At a much coarser scale, measurements of the width of the Russian forest-tundra (mapped by Lavrenko and Sochava, 1954) were made to extend a comparison of forest-tundra widths to the circumpolar scale. Factors that might account for the observed vegetation patterns were sought by reference to studies of subarctic climate, soils, parent materials, and vegetation and, for local elevations and landforms, by reference to the airphoto database constructed for this study.

\section{RESULTS}

\section{Regional Vegetation-Synoptic Climate Anomalies}

1. McTavish Arm, Great Bear Lake to east of the Coppermine River: High tree cover (> 50\%) extends a great distance eastward from McTavish Arm of Great Bear Lake, to the north of Point Lake and west of Takiyuak Lake (Fig. 1). From Takiyuak Lake south to Point Lake, the limit of trees lies virtually north-south, with high cover extending a short distance east of the Coppermine River valley. Both topoclimate and parent materials/soils appear to be involved in this pattern.

Elevation rises steeply eastward from $156 \mathrm{~m}$ at Great Bear Lake to $300 \mathrm{~m}$ in about $10-25 \mathrm{~km}$, and continues to rise to 460 $\mathrm{m}$ in another $40-60 \mathrm{~km}$. Elevations plateau at $425-500 \mathrm{~m}$ for $40-50 \mathrm{~km}$ then fall to about $400 \mathrm{~m}$ in the broad valley of the upper Coppermine. East of the Coppermine, trees do not rise above $450 \mathrm{~m}$ asl.

A transition from acidic Archean crystalline rocks east of McTavish Arm to Archean sediments and metasediments overlain by basic silt loams in the Coppermine River area coincides with the elevation gradient. The limit of trees east of the Coppermine parallels a transition back to acidic crystalline rocks.

Tree cover in the area shows some correlations with the bedrock. Locations having high tree cover, in general, are underlain by carbonates, slates, greywacke, conglomerates, other sediments, and their derived schists and gneisses. Areas of low tree cover are frequently underlain by acidic granitic gneisses and related crystalline rocks and volcanics. Farther south, near Winter Lake, where the underlying bedrock is granitic gneisses and related rocks, black spruce dominates forest-tundra tree communities; white spruce is usually restricted to glaciofluvial deposits and local circumneutral soils $(\mathrm{pH} \geq 5.5)$. 


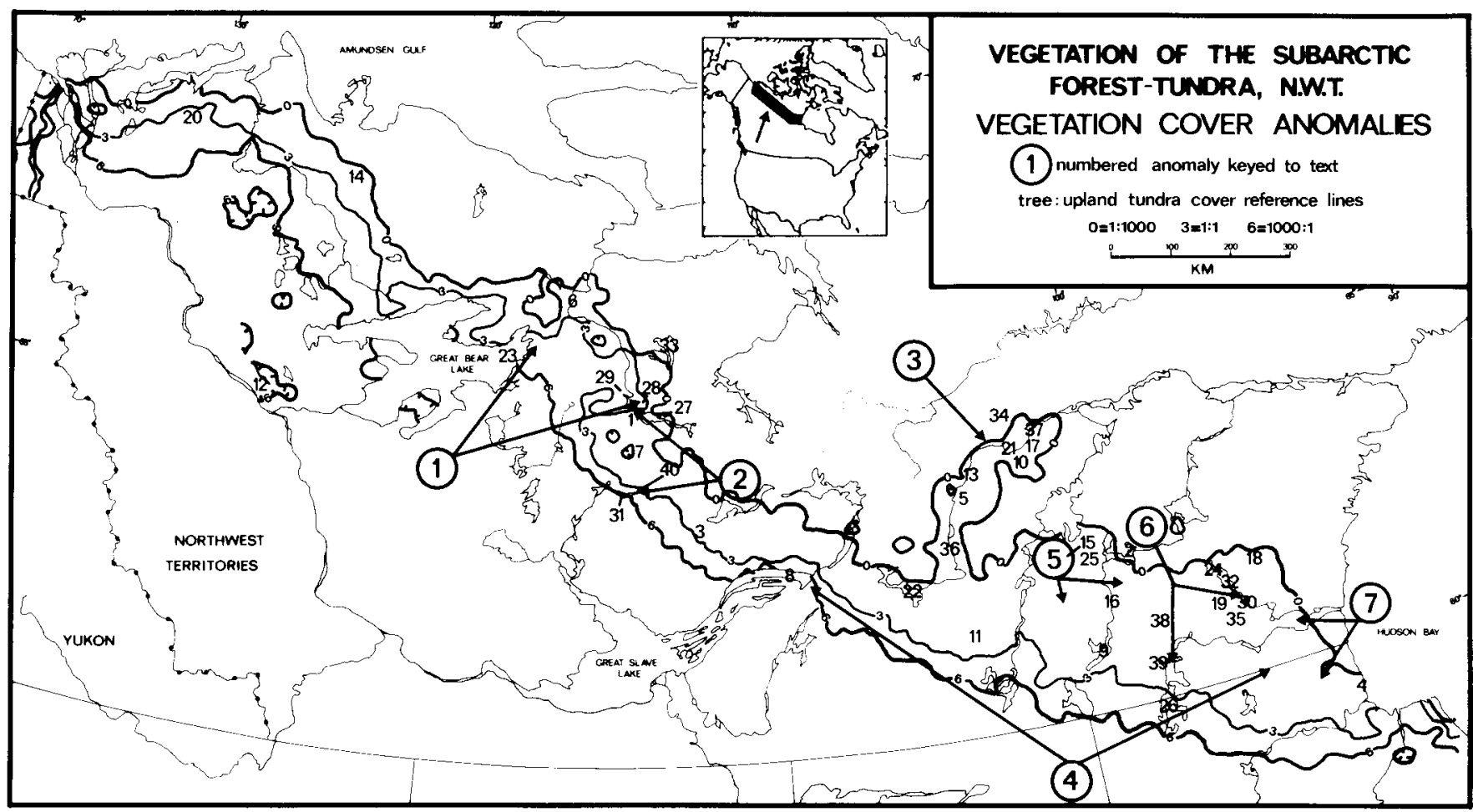

FIG. 1. Tree cover anomalies in the subarctic forest-tundra of northwestern Canada. Numbered regional anomalies are (1) McTavish Arm, Great Bear Lake, to east of Coppermine River; (2) Snare to Rocknest-Point Lakes; (3) Thelon River; (4) Great Slave Lake to east Keewatin-Manitoba; (5) Kamilukuak Lake to Kazan River; (6) Nueltin-Hicks-Henik Lakes region; (7) SE Keewatin and NE Manitoba. Place names are plotted as: 1, "1314” Lake; 2, Angikuni Lake; 3, Beniah; 4, Caribou River; 5, Clarke River; 6, Coppermine River; 7, Drumlin Lake; 8, East Arm; 9, Ennadai; 10, Finnie River; 11, Firedrake; 12, Franklin Mountains; (Henik: see South and North Henik Lakes); 13, Hornby; 14, Horton; 15, Kamilukuak Lake; 16, Kazan River; 17, Kigarvi River; 18, Kinga Lake; 19, Kognak River; 20, Kugaluk; 21, Lookout Point; 22, Lynx Lake; 23, McTavish Arm; 24, North Henik Lake; 25, Nowleye Lake; 26, Nueltin Lake; 27, Point Lake; 28, Redrock Lake; 29, Rocknest Lake; 30, Roseblade Lake; 31, Snare Lake; 32, South Henik Lake; 33, Takiyuak Lake; 34, Tammarvi River; 35, Tatinnai Lake; 36, Thelon River; 37, Ursus Islands; 38, Watterson Lake; 39, Windy Bay; 40, Winter Lake.

2. Snare to Rocknest-Point Lakes: A transect north from Snare Lake to the Coppermine River north of Rocknest Lake (Fig. 2) illustrates how apparent vegetation anomalies may be reconcilable when local conditions are known. Tree cover drops from $>85 \%$ at Snare Lake to $10 \%$ in about $27 \mathrm{~km}$, and then to $0.6 \%$ by $50 \mathrm{~km}$ north of Snare Lake, where black spruce disappears from the landscape. Northward, white spruce is the sole tree present and it thins to $0.3 \%$ or less from south of Drumlin Lake to north of "1314" lake on the highland south of Redrock Lake. About $12 \mathrm{~km}$ south of Redrock Lake, white spruce begins to increase in cover, rising rapidly in cover northward till by the narrows between Redrock and Rocknest Lakes, white spruce occupies $>70 \%$ of the landscape, and maintains this high cover northward. Dominant vegetation at Snare Lake is a moist black spruce/dwarf birch (Betula glandulosa Michx.)/ericad woodland. Dominant vegetation along the Coppermine River north of Rocknest Lake is a white spruce/dwarf birch-shrub/TomenthypnumRhytidium forest with many calciphiles.

Low elevations, sedimentary bedrock, and calcareous soils are correlated with high tree cover along the transect. Mean elevation rises from $\sim 375 \mathrm{~m}$ asl at Snare Lake to $>450$ $\mathrm{m}$ midway between Snare and Rocknest Lakes, then falls again to $\sim 400 \mathrm{~m}$ by the valley of the Coppermine. A maximum elevation of $>520 \mathrm{~m}$ is reached south of the Coppermine. Bedrock is predominantly Archean granitic gneisses in the south, but changes to a complex of many rocks (mostly sedimentary) by the valley of the Coppermine. Soils at Snare Lake are sandy Brunisols with a $\mathrm{pH}$ of $\sim 4.5-5.5$ in the Bm horizon; soils along the Coppermine River north of Rocknest Lake are silt loam Gleysolic Cryosols with a pH of 7.5.

3. Thelon River: Of all northern extensions and outliers of the forest-tundra in the N.W.T., the Thelon "oasis" is perhaps the most striking. High tree cover (10-20\%) along the Thelon valley occupies an "island" extending from $63^{\circ} 47^{\prime} \mathrm{N}$ (Grassy Island) northeast to $64^{\circ} 18^{\prime} \mathrm{N}, 101^{\circ} 55^{\prime} \mathrm{W}$ ("Deer Pass," upstream of the Ursus Islands) (this study; A. Hall, pers. comm. 1995), suggesting these tree stands are relictual outliers, but evidence for this is lacking.

Clarke (1940) concluded that tree stands on the Thelon are more often expanding than contracting in area. He surmised that Thelon forest stands may have changed little for hundreds of years. Other workers have noted the vigorous growth and reproduction of trees along the Thelon (C. Norment, pers. comm., in Larsen, 1980; E. Kuyt, pers. comm. 1988; S.C. Zoltai, pers. comm. 1988). At Hornby cabin, white spruce trees appear healthy, with no visible signs of stress (D'Arrigo et al., 1992).

Air and ground level photos indicate well-developed forest on the alluvial flats of the Thelon and its tributaries (e.g., the Clarke River near $104^{\circ} \mathrm{W}$ ). Forests grade upward into forest-tundra on the gentle valley slopes of the Thelon and 

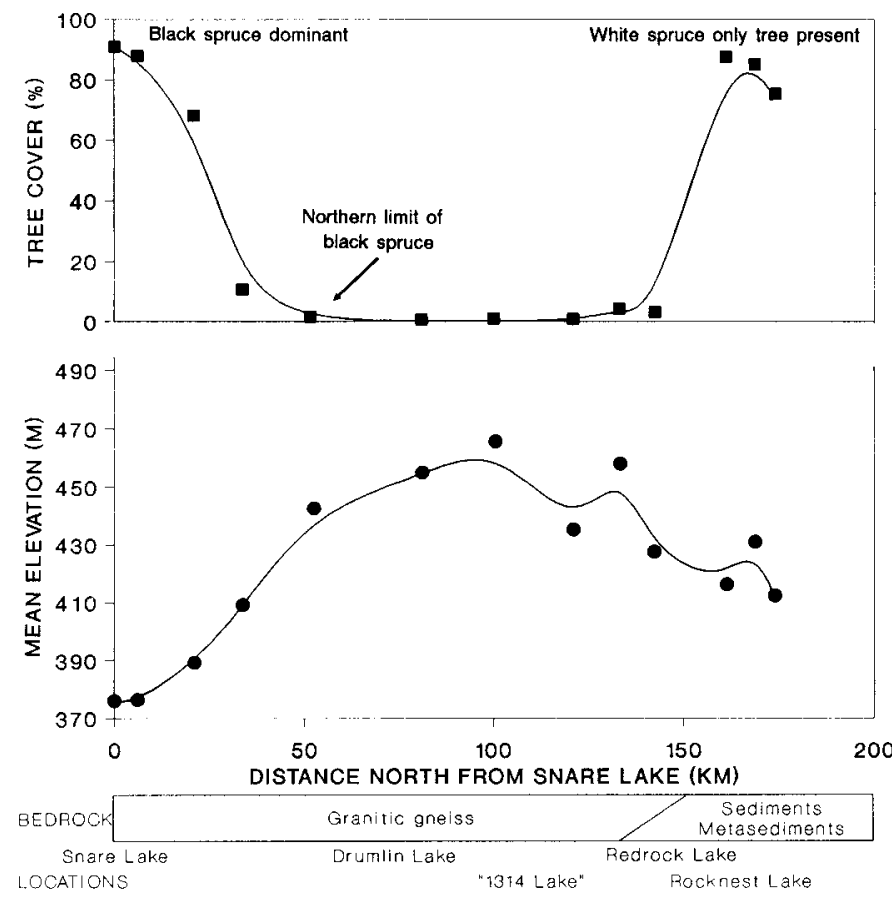

FIG. 2. Tree cover, mean elevation, and bedrock changes on a south to north transect between Snare and Rocknest Lakes. See anomaly 2 for description.

elsewhere. Clarke (1940) observed the most luxuriant growth of spruce along the Thelon in a place where springs emerged from sandstone, and on the silty alluvium of Finnie River flats, where white and black spruce together with larch form an extensive stand.

White spruce is overwhelmingly the predominant tree in forest stands. Black spruce and larch occur along with white spruce, and numerous seedlings have been reported in many stands (Clarke, 1940; C. Norment, pers. comm., in Larsen, 1980). E. Kuyt (pers. comm. 1988) observed some black spruce on slopes and balsam poplar on alluvium. Balsam poplars are shrubby, with diameters $<2.5-5 \mathrm{~cm}$; a grove of apsen with trees $25 \mathrm{~cm}$ in diameter exists near the HanburyThelon junction (A. Hall, pers. comm. 1995). At Lookout Point, Kuyt noted some white spruce that measured $40 \mathrm{~cm}$ diameter at the butt. Alex Hall, a river guide who has canoed the Thelon River 33 times, notes: "I have seen many trees in the oasis that I couldn't reach my arms around...there are trees...in excess of $80 \mathrm{~cm}$ diameter" (A. Hall, pers. comm. 1995). If Hall's observations are accurate, these white spruce are the largest diameter trees ever recorded at the Canadian tree line. Tree stands along the Thelon and its tributaries, at least in the absence of disturbance, presently seem capable of maintenance and even expansion in area.

Parent materials are reported as sandy and silty alluvium, and red till derived from Dubawnt sandstone (Clarke, 1940; Bradley et al., 1984). Red tills have a median $\mathrm{pH}$ of 5.1, low cation exchange capacity, loamy sand texture, and are relatively low in nitrogen, calcium, and magnesium; they do not differ significantly from acidic Shield tills (Timoney et al., 1993a). The relatively nutrient-poor red tills, and the alluvium (limited in areal extent), taken together, cannot account for the extensive forests of the oasis. Runnel occurrence is higher along the middle Thelon than on typical Shield terrain, indicating long, well-watered slopes, and suggesting that a fine-textured glacio-lacustrine veneer overlies the other deposits (airphoto observations). A glacio-lacustrine veneer is further suggested by Geological Survey of Canada (1976), which maps the area as lake deposits. Hall (pers. comm. 1995) notes that the soils of the Thelon oasis differ from soils elsewhere on the Thelon in their finer texture; extensive, dense and tall alluvial willow thickets (shrubland) also typify the oasis. The latter four observations suggest that edaphic compensation on fine-textured soils (see Discussion) may play a significant role in accounting for the Thelon oasis.

Low elevations may further help to explain the high cover of forest. The valley of the Thelon and its major tributaries such as the Clarke, Finnie, Tammarvi, and Kigarvi Rivers are protected relative to the treeless interfluves. Mean and minimum elevations for the Thelon valley north of $64^{\circ} \mathrm{N}$ are $60 \mathrm{~m}$ lower than means and minima out of the valley, which translate to a temperature difference of $0.5^{\circ} \mathrm{C}$ (summer lapse rate of $0.8^{\circ} \mathrm{C}^{\cdot} 100 \mathrm{~m}^{-1}$ after Burns, 1974). Mean elevations outside the valley lie $90 \mathrm{~m}$ above valley minima (lapse rate difference $0.7^{\circ} \mathrm{C}$ ).

Northward fall of elevation may also contribute to high forest cover. Mean elevation near Howard and Lynx Lakes on the upper Thelon is $370 \mathrm{~m}$. By comparison, mean elevation of the Thelon north of $64^{\circ} \mathrm{N}$ is $220 \mathrm{~m}$ lower, and its minimum elevation is $250 \mathrm{~m}$ lower. Northward fall in elevation translates to a lapse rate temperature difference of $+1.8-2.0^{\circ} \mathrm{C}$. When compared to mean July temperatures for eastern Mackenzie District (Hare and Hay, 1974), a $2^{\circ} \mathrm{C}$ difference corresponds to $300 \mathrm{~km}$ of SW-NE gradient $\left(1^{\circ} \mathrm{C} \cdot 150 \mathrm{~km}^{-1}\right)$. In close agreement, the upper forest limit in the mountains of Russia rises $\mathrm{N}-\mathrm{S}$ about $100 \mathrm{~m}$ per degree of latitude (Gorchakovsky and Shiyatov, 1978), corresponding to a warming of $1^{\circ} \mathrm{C} \cdot 150 \mathrm{~km}^{-1}$.

Large, deep lakes, which would have a chilling effect on summer temperatures and delay the onset of the growing season (McFadden, 1965), are absent from the Thelon grove. Indeed, the absolute limit of trees is reached at Beverly Lake, the first lake north of the grove. Thus, northward fall of elevation, and the absence of large lakes, may make the Thelon valley something of a thermal oasis.

A thermal oasis is corroborated by Hall (pers. comm. 1995): in July and August, daytime temperatures of from $15^{\circ} \mathrm{C}$ to $30^{\circ} \mathrm{C}$ may persist "for many weeks on end... by midJuly, the Thelon River is usually warm enough to swim in all day without getting cold...river water is usually above $15^{\circ} \mathrm{C}$ most of July and August... The Thelon is a very warm place."

Bioclimatic feedback among vegetation, snow cover, and radiation may be important in maintenance of the high tree cover, although not in its establishment. In the main "island" of trees and tall shrubs along the middle Thelon, mean tree cover is $14 \%$ and shrubland cover is $6 \%$. Thus, $20 \%$ of the landscape has a relatively low albedo and a rough surface capable of lodging snow and decreasing wind.

It is possible that the Thelon is dissimilar climatically to 
the tree line as a whole. The Hornby site appears to reflect different climatic conditions from other northern tree line sites, at least in regard to tree ring widths. Hornby shows a steady decline in white spruce ring widths since the 1930s, while two sites along the north Coppermine River and in the Franklin Mountains show a strong net increase in ring widths (D'Arrigo et al., 1992). In summary, it appears that both a climatic oasis effect and favourable soils, reinforced by bioclimatic feedback, may account for the remarkable Thelon outlier of the forest-tundra.

4. Great Slave Lake to eastern Keewatin-Manitoba: The forest-tundra increases in width from the East Arm of Great Slave Lake ( $70 \mathrm{~km}$ minimum) to eastern Keewatin-Manitoba (338 km maximum). It is unlikely that synoptic climate can wholly account for this pattern. While the northern portion of the forest-tundra there has been considered relictual (Nichols, 1976; Elliott-Fisk, 1983), there are difficulties with this view stemming from both the interpretation of paleoecological data and what constitutes "relict" vegetation (LichtiFederovich and Ritchie, 1968; Ritchie and Hare, 1971; Walker et al., 1981; Payette, 1983).

Another possibility that may account for the great width of the southeastern forest-tundra has been outlined for northern Québec. Payette and Gagnon (1985:570) view the Québec forest-tundra itself as the result of fire, the "product of a once densely-populated coniferous zone that experienced a longterm deforestation." There is as yet no evidence to support this view for the southeastern forest-tundra. Currently, the northern limit of burns generally extends only $25-75 \mathrm{~km}$ into the forest-tundra there, and not beyond the line where tree cover equals upland tundra cover (Timoney and Wein, 1991). Paleoecological studies are needed.

An alternative interpretation of the southeastern foresttundra cover pattern involves edaphic controls and the northeast fall of elevation. On average, elevations fall 100-150 m from SW to NE, corresponding to a compensatory summer warming of $\sim 0.8-1.2^{\circ} \mathrm{C}$ (summer lapse rate after Burns, 1974). July mean temperature for the southeastern foresttundra ranges $2^{\circ} \mathrm{C}$, from $11^{\circ} \mathrm{C}$ to $13^{\circ} \mathrm{C}$ (Timoney et al., 1992); thus, a $1^{\circ} \mathrm{C}$ compensatory summer warming might contribute to the gradual vegetation gradients.

An exception to the NE fall of elevation provides further indication of topoclimatic effects. The highland between Nueltin Lake and the Watterson-Hicks Lakes area is characterized by a steep fall in tree cover (Fig. 1: anomaly 6).

5. Kamilukuak Lake to Kazan River: The area lying between $102^{\circ} \mathrm{W}$ and $100^{\circ} \mathrm{W}$, south of Kamilukuak, Nowleye, and Angikuni Lakes, and north of $61^{\circ} 30^{\prime} \mathrm{N}$ supports a high cover of trees and tall shrub. Trees there include black and white spruce and larch. Mean tree cover in the area is $8 \%$, and that for tall shrub is $7 \%$. Peak tree cover (14\% to $23 \%)$ is reached both east and west of the Kazan River near latitude $62^{\circ} \mathrm{N}$, while that for tall shrub ranges from 5\% to $23 \%$.

Bedrock type (Geological Survey of Canada, 1968) shows little or no correlation with the vegetation patterns. The land slopes to the NE, falling about $60-100 \mathrm{~m}$ in about $80 \mathrm{~km}$, which may contribute to the high tree cover.
Tall shrub attains high cover, indicative of well-watered sites, and tree cover is closely correlated with tall shrub cover in the $\operatorname{area}(\mathrm{r}=0.70,0.01>p>0.001)$. Preferred terrain types for spruce and larch in this area are drainages, slopes and slope bases, shores, low-lying areas, and depressions. Combined tree and shrubland cover in the core area ranges from $20 \%$ to $45 \%$; thus bioclimatic feedback may act to maintain the high tree cover.

6. Nueltin-Hicks-Henik Lakes region: Peaks $(\geq 20 \%)$ and depressions $(<2 \%)$ in tree cover contrast with a typical regional cover of $2 \%$ to $10 \%$. Regional vegetation is dominated by dwarf birch/ericad tundra ( $\geq 75 \%$ of the land). Near north Nueltin Lake (Windy Bay), black spruce is the dominant tree, associated with larch in "muskegs" and on upland slopes. White spruce is sparse and local, and paper birch and balsam poplar are rare. Most trees do not exceed 7.5-9 $\mathrm{m}$ in height (F. Harper, pers. comm., in Porsild, 1950). Tree cover peaks below the $230 \mathrm{~m}$ contour at $\sim 20 \%$ in the vicinity of South Henik Lake, Kognak River, and Tatinnai and Roseblade Lakes. Black spruce is more abundant than white spruce there, and larch is locally dominant (airphoto observations; Zoltai and Johnson, 1978).

Topoclimate is important in accounting for the variations in tree cover. Airphotos in the area were classified into those of "high" tree cover $(\geq 10 \%$; mean $18 \% \pm 5.2 \mathrm{SD}$; median $19 \%, \mathrm{n}=10)$ and those of "low" tree cover $(\leq 5 \%$; mean $3 \%$ $\pm 1.6 \mathrm{SD} ;$ median $3 \%, \mathrm{n}=13$ ). Areas of high tree cover were found at lower mean $(247 \pm 53 \mathrm{~m})$ and minimum elevations $(223 \pm 46 \mathrm{~m}$ ) than areas of low tree cover (mean elevation 296 $\pm 40 \mathrm{~m}$; minimum elevation $277 \pm 37 \mathrm{~m}$; t-test mean elevation: $\mathrm{t}=2.44,21$ d.f., $p \sim 0.03$; t-test minimum elevation: $\mathrm{t}=$ $3.02,21$ d.f., $p<0.01$ ). It is evident that an elevation difference of as little as $50 \mathrm{~m}$ may have a significant effect on tree cover. Elevations fall from $>300 \mathrm{~m}$ in the southeast to $<150 \mathrm{~m}$ east of the Henik Lakes (compensatory summer warming of $\sim 1.2{ }^{\circ} \mathrm{C}$ ) across $110-120 \mathrm{~km}$, thus contributing to the great breadth of the forest-tundra (see anomaly 4 ).

The same data set was tested for the influence of bedrock. Because each airphoto covers an area of roughly $225 \mathrm{~km}^{2}$, the bedrock types were necessarily broad categories. Areas of high tree cover show a tendency to be found on non-sedimentary complex bedrock (including basic volcanics), and those of low tree cover found on acidic crystalline bedrock $\left(\chi^{2}=\right.$ $3.35,1$ d.f., $p \sim 0.07)$. It is understandable that tree cover does not show a stronger linkage with bedrock in the area, since glacial dispersion has blurred the relationship between soils and underlying bedrock (Shilts, 1980).

7. SE Keewatin and NE Manitoba: The limit of trees drops abruptly SSE along a line east of $96^{\circ} \mathrm{W}$, lying between the 150-75 m contours in SE Keewatin, reaching the shore of Hudson Bay a short distance north of the Caribou River, northern Manitoba. There, black spruce and larch are the dominant trees; white spruce is best developed along water courses and the margins of glaciofluvial deposits, and forms the last outposts of trees in the Kinga Lake area (airphoto observations; Hardy and Associates, 1976). Tree and upland tundra contours show no clear relationship to the limit of postglacial marine overlap (cf. Geological Survey of Canada, 1967). 
Below the 150 m contour and roughly correlating with the limit of trees, wetland increases sharply in cover from $+10 \%$ in the west to $25-50 \%$ in the east, where it comes to dominate the landscape. By the shores of Hudson Bay, wetland cover rises to $>75 \%$. Countless ponds and small lakes dot the landscape along the wetland-dominated margin of Hudson Bay. Much of this wetland is likely incapable of supporting trees regardless of the climate.

The distance to which cold, moist marine air extends inland is unknown. The $10^{\circ} \mathrm{C}$ mean July air isotherm turns south upon reaching Hudson Bay, as does the 60-day contour for frost-free period (Hare and Hay, 1974). Such a deterioration of the growing season may be important in the southward plunge of the tree line. In comparison, the Russian foresttundra is oriented parallel to the shores of the Arctic Ocean, and extends northward to the world's most northern forests $\left(72^{\circ} 40^{\prime} \mathrm{N}\right)$ on the broad Taimyr Peninsula (Tikhomirov, 1970). Similarly, the forest-tundra in eastern Canada extends farthest north near the centre of the Labrador-Ungava peninsula, and turns southward along the shores of Hudson Bay and the Labrador Sea (Payette, 1983).

\section{DISCUSSION}

\section{A theory of edaphic influences upon the forest-tundra}

Edaphic conditions exert a stronger control over tree distribution on nutrient-poor, dry sandy soils in the foresttundra than on nutrient-rich moist soils. Thus, trees on unfavorable terrain should be found in the patchwork of sites where moisture, nutrients, snowcover, etc. are amenable to reproduction and survival. Favorable sites might support trees up to a species' climatic limits, but much of the landscape would become treeless farther south. On unfavorable terrain, the forest-tundra would be both wider and located southward of forest-tundra on favorable terrain. Moist, nutrient-rich terrains, in contrast, may allow high landscape cover of trees to extend northward until absolute climatic thresholds are reached.

\section{Evidence in support of edaphic influences}

The northwestern forest-tundra transition is relatively narrow and its zone of steep tree and tundra cover gradients (tree line) is located near the northern limit of the foresttundra (Fig. 3a, b; also Timoney et al., 1992). Conversely, on the nutrient-poor terrain of the southeast, steep tree and tundra gradients are located in the southern forest tundra, with a patchwork of sites retaining trees well to the north (Fig. $3 \mathrm{c}, \mathrm{d})$. There the forest-tundra is broad and its tree line proper (zone of steep tree and tundra gradients) lies climatically southward of its counterpart in the northwest. The absolute limit of trees in southern Keewatin coincides well with a theoretical tree line calculated by extrapolation of black spruce growth indices (Mitchell, 1973), and lies about 290 $\mathrm{km} \mathrm{NE}$ of the tree line proper.
Edaphic factors through their influence on species composition and ecophysiology may affect both the width and position of the forest-tundra. Fine-textured loams, typical of the northwest, retain more freely available water than sandy soils. Because they retain more water which evolves latent heat of fusion, freezing and thawing occur later in finetextured soils than in coarse soils (Geiger, 1965; Viereck, 1970). Indeed dry, coarse-textured soils and shallow soils over bedrock are among the first to lose their trees at the southern edge of the forest-tundra (Lindsey, 1952; Payette, 1983; Timoney et al., 1993a).

While black spruce and white spruce appear to have similar nutrient use efficiency for nitrogen, phosphorus, and potassium (Van Cleve et al., 1983), the slower-growing black spruce tolerates lower levels of nitrogen. Foliar N concentrations of $0.86 \%$ are deficient for black spruce, whereas white spruce foliage is deficient at $1.21 \%$ (Morrison, 1974). Black spruce appears to use calcium and magnesium more efficiently than does white spruce (Van Cleve et al., 1983), a possible advantage on poor soils. Soil nitrogen, calcium, and magnesium levels appear to be deficient for white spruce on Shield acidic tills (Morrison, 1974; Timoney et al., 1993a). Edaphic restriction in the southeast may therefore limit the abundance of white spruce. When they occur together, white spruce tends to occupy warmer, nutrient-rich sites while black spruce dominates the colder, nutrient-poor soils (Bonan, 1992).

The shift from black spruce to white spruce dominance is likely related to reproductive inhibition of black spruce in the colder northwest (Fraser, 1971; Black, 1977; Timoney et al., 1992). The favorable terrain of the northwest may in part compensate for the lower temperatures and net radiation there and permit the nutrient-demanding, faster-growing, cold-adapted white spruce to reach its absolute climatic limits.

In contrast, the dominance of black spruce over white spruce on the acidic soils of the Shield may be related to the former's more efficient use of scarce nutrients and its tolerance of slow growth rates. Thus the forest-tundra there may be located climatically farther south because the less coldadapted black spruce is dominant.

Migrational history probably plays little or no role in cover anomalies. The major constituent species reached the vicinity of tree line sometime during the early to mid-Holocene, and have since fluctuated in their areal extent over the centuries (Nichols, 1967; Elliott-Fisk, 1983; Ritchie, 1984; Ritchie and MacDonald, 1986). The striking floristic difference between the northwest and southeast is unrelated to migration, as most forest-tundra plants are transcontinental in range (Timoney et al., 1993a). In particular, most boreal tree species stopped their migrations a few thousand years ago (Payette, 1992). The marked floristic differences between the northwest and southeast are due to abrupt changes in the stand frequencies of the species in the regional vegetation rather than to their absence from the flora.

Corroborative evidence in support of edaphic influences is provided by comparison of the soils, vegetation, and climate of subarctic Russia (Lavrenko and Sochava, 1954; Nalivkin, 1960; Sachs and Strelkov, 1960; Academy Sciences USSR, 

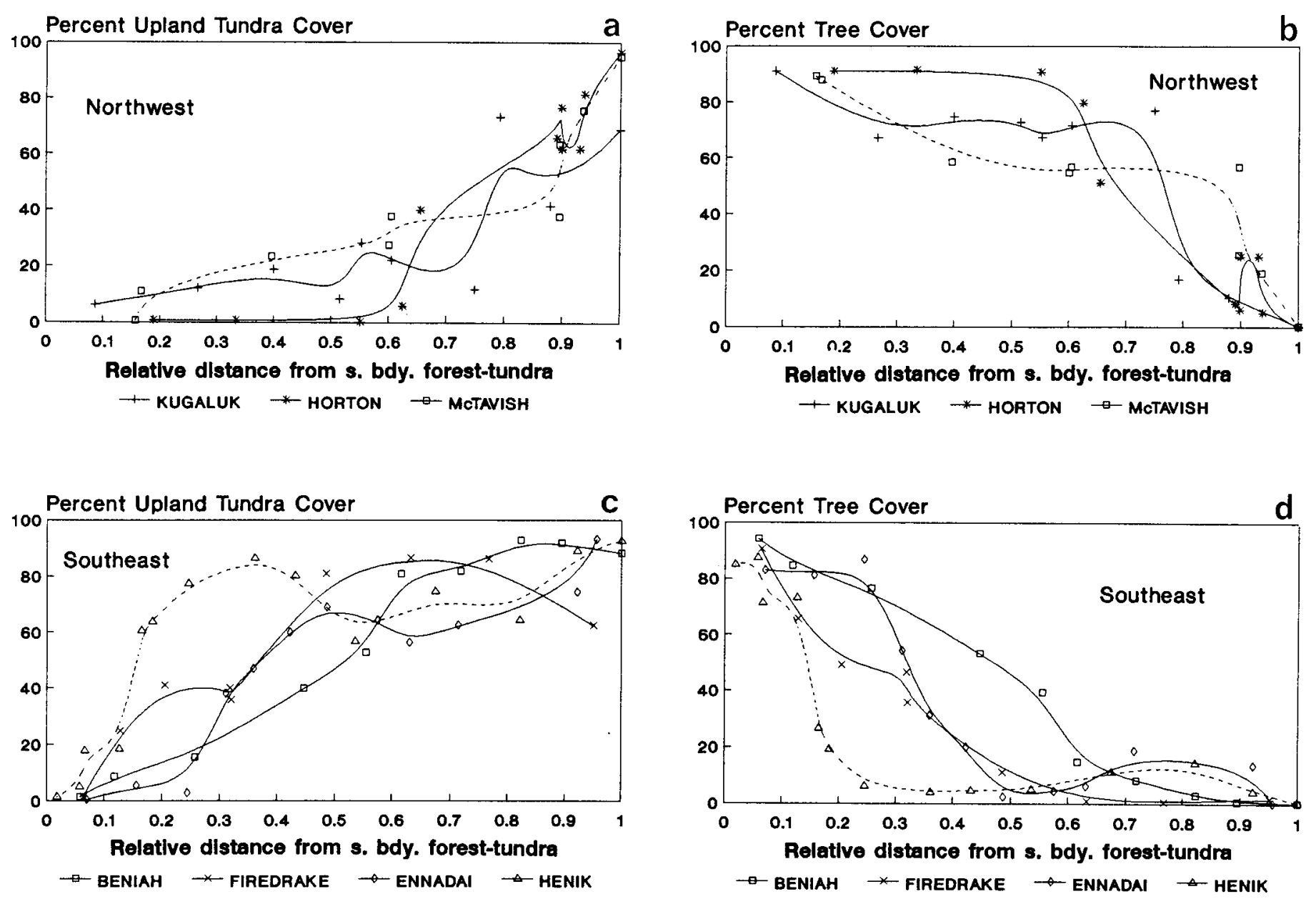

FIG. 3. Latitudinal profiles of upland tundra and tree cover in the northwest and southeast sectors of the forest-tundra of northwestern Canada.

1963; Lydolph, 1977). The Russian forest-tundra is broadest $(\sim 100 \pm 60 \mathrm{~km} \mathrm{S.D.)}$ where it lies south of its climatic potential. These regions lie (a) east of Cheshskaya Guba $\left(47^{\circ} \mathrm{E}\right)$ and west of the Ural Mountains $\left(61^{\circ} \mathrm{E}\right)(65 \pm 20 \mathrm{~km}$ wide), and (b) east of Obskaya Guba $\left(75^{\circ} \mathrm{E}\right)$ extending to about $120 \mathrm{~km}$ east of the Yenisey River $\left(85^{\circ} 30^{\prime} \mathrm{E}\right)(140 \pm 60$ $\mathrm{km}$ wide). Both of these regions are low-lying plains having a high cover of Sphagnum bogs. Mineral soils are developed primarily on sandy loam and sandy fluvial and lacustrine deposits; permafrost is scattered to widely distributed (Lydolph, 1977).

In contrast, most of the forest-tundra between the Yenisey and Kolyma Rivers $\left(158^{\circ} \mathrm{E}\right)$ is narrow $(50 \pm 30 \mathrm{~km}$ wide $)$ and underlain by Cretaceous, Triassic, and Jurassic sediments. Quaternary alluvium and lacustrine sediments are prominent between the Yana $\left(135^{\circ} \mathrm{E}\right)$ and Kolyma Rivers (cf. Lavrenko and Sochava, 1954; Nalivkin, 1960; Velichko, 1984). The climate of the Yana-Kolyma forest-tundra region is harsh; permafrost is continuous and soils are predominantly Gleysolic Cryosols, indicative of fine soil textures (see Academy Sciences USSR, 1963; Karavaeva and Targul'yan, 1969; Lydolph, 1977); the forest-tundra spans only $40 \pm 20 \mathrm{~km}$.

\section{ACKNOWLEDGEMENTS}

For their insight, encouragement, and support I thank George La Roi, Stephen Zoltai, and Anne Robinson. For the initial inspiration to learn about the tree line I thank Jim Larsen. Alex Hall provided a wealth of observations from the Thelon River. I thank anonymous reviewers for their criticisms. Anne Robinson, Greg Shantz, Jim Donaldson, and Patrick O'Leary were friends and companions on land and water.

\section{REFERENCES}

ACADEMY OF SCIENCES USSR. 1963. Soil-geographical zoning of the USSR. Council for the Study of Productive Resources, Dokuchaev Soil Institute. Jerusalem: Israel Program for Scientific Translations.

BARBOUR, M.G., BURK, J.H., and PITTS, W.D. 1980. Terrestrial plant ecology. Menlo Park, California: Benjamin/Cummings Co.

BLACK, R.A. 1977. Reproductive biology of Picea mariana (Mill.) BSP at treeline. Ph.D. thesis, Department of Botany, University of Alberta, Edmonton, Alberta, Canada.

BONAN, G.B. 1992. Soil temperatures as an ecological factor in boreal forests. In: A systems analysis of the global boreal forest. New York: Cambridge University Press. 126-143. 
BRADLEY, S.W., ROWE, J.S., and TARNOCAI, C. 1982. An ecological land survey of the Lockhart River map area, Northwest Territories. Ottawa: Ecological Land Classification Series 16.

BURNS, B.M. 1974. The climate of the Mackenzie Valley. Toronto: Environment Canada, Climatological Studies, No. 24. Two vols.

CAIN, S. 1944. Foundations of plant geography. New York: Harper $\&$ Brothers.

CLARKE, C.H.D. 1940. A biological investigation of the Thelon Game Sanctuary. Ottawa: National Museum of Canada, Bulletin 96 (Biological Series No. 25).

D'ARRIGO, R.D., JACOBY, G.C., and FREE, R.M. 1992. Treering width and maximum latewood density at the North American tree line: Parameters of climatic change. Canadian Journal of Forest Research 22(9):1290-1296.

DOLGIN, I.M. 1970. Subarctic meteorology. In: Ecology of the subarctic regions. Proceedings of the Helsinki Symposium, 25 July-3 August 1966. Paris: UNESCO. 41-61.

ECOREGIONS WORKING GROUP. 1989. Ecoclimatic regions of Canada. Ecological Land Classification Series, No. 23, Canadian Committee on Ecological Land Classification. Ottawa: Lands Directorate, Environment Canada.

ELLIOT-FISK, D.L. 1983. The stability of the northern Canadian tree limit. Annals of the Association of American Geographers 73(4):560-576.

FRASER, J.W. 1971. Cardinal temperatures for germination of six provenances of white spruce seed. Ottawa: Department of Fisheries and Forestry, Canadian Forestry Service, Publication No. 1290.

FRITTS, H.C. 1971. Dendroclimatology and dendroecology. Quaternary Research 1:419-449.

GEIGER, R. 1965. The climate near the ground. Cambridge, Massachusetts: Harvard University Press.

GEOLOGICAL SURVEY OF CANADA. 1967. Glacial map of Canada. Map 1253A. Ottawa: Dept. of Energy, Mines, and Resources. Scale 1:5000 000.

- 1968. Geological map of Canada. Map 1250A. Ottawa: Dept. of Energy, Mines, and Resources. Scale 1:5000 000.

GORCHAKOVSKY, P.L., and SHIYATOV, S.G. 1978. The upper forest limit in the mountains of the boreal zone of the USSR. Arctic and Alpine Research 10(2):349-363.

HARDY, R.M., and ASSOCIATES LTD. 1976. Landscape survey, District of Keewatin, N.W.T. Toronto: Polargas.

HARE, F.K., and HAY, J.E. 1974. The climate of Canada and Alaska. In: Bryson, R.A., and Hare, F.K., eds. World survey of climatology. Vol. 11: Climates of North America. New York: Elsevier. 49-192.

HUOVILA, S. 1970. Some features of the microclimate within hilly regions of Finland. In: Ecology of the subarctic regions. Proceedings of the Helsinki Symposium, 25 July-3 August 1966. Paris: UNESCO. 63-66.

KARAVAEVA, N.A., and TARGUL'YAN, V.O. 1969. Contribution to the study of soils on the tundras of northern Yakutia. In: Ivanova, E.N., ed. Soils of Eastern Siberia. Translated by A. Gourevitch. Jerusalem: Israel Program for Scientific Translations. 57-78.

LARSEN, J.A. 1980. The boreal ecosystem. New York: Academic Press.

LAVRENKO, E.M., and SOCHAVA, V.B., eds. 1954. The geobotanical map of the USSR. Leningrad: Academy of Sciences
USSR, Komarov Botanical Institute. Eight sheets. Scale 1:4 000 000. Legend in English translation by E.M. Lavrenko and V.M. Ponjatovskaja, 1956.

LICHTI-FEDEROVICH, S., and RITCHIE, J.C. 1968. Recent pollen assemblages from the western interior of Canada. Review Paleobotany Palynology 7:297-344.

LINDSEY, A.A. 1952. Vegetation of the ancient beaches above Great Bear and Great Slave Lakes. Ecology 33(4):535-549.

LYDOLPH, P.E. 1977. Climates of the Soviet Union. World Survey of Climatology. Vol. 7. New York: Elsevier.

McFADDEN, J.D. 1965. Interrelationships of lake ice and climate in central Canada. Washington, D.C.: Office of Naval Research, Technical Report 20.

MITCHELL, V.L. 1973. A theoretical tree line in central Canada. Annals of the Association of American Geographers 63(3): 296-301.

MORRISON, I.K. 1974. Mineral nutrition of conifers with special reference to nutrient status interpretation: A review of literature. Department of the Environment, Canadian Forestry Service Publication 1343.

NALIVKIN, D.V. 1960. The geology of the USSR: A short outline. International Series of Monographs in the Earth Sciences, Vol. 8. Translated by S.I. Tomkeieff. New York: Pergamon Press. Includes geological map. Scale: 1:7 500000.

NICHOLS, H. 1967. Pollen diagrams from sub-arctic central Canada. Science 155:1665-1668.

1976. Historical aspects of the northern Canadian treeline. Arctic 29:38-47.

PAYETTE, S. 1983. The forest tundra and present tree-lines of the northern Québec-Labrador peninsula. In: Morisset, P. and Payette, S., eds. Tree-line ecology: Proceedings of the Northern Québec Tree-Line Conference. Nordicana 47:3-23.

_ 1992. Fire as a controlling process in the North American boreal forest. In: Shugart, H.H., Leemans, R., and Bonan, G.B., eds. A systems analysis of the global boreal forest. New York: Cambridge University Press. 144-169.

PAYETTE, S., and GAGNON, R. 1985. Late Holocene deforestation and tree regeneration in the forest-tundra of Québec. Nature 313:570-572.

PORSILD, A.E. 1950. Vascular plants of Nueltin Lake, Northwest Territories. Ottawa: National Museum of Canada, Bulletin 118:72-83.

RITCHIE, J.C. 1984. Past and present vegetation of the far northwest of Canada. Toronto: University of Toronto Press.

RITCHIE, J.C., and HARE, F.K. 1971. Late-Quaternary vegetation and climate near the arctic tree line of northwestern North America. Quaternary Research 1:331-342.

RITCHIE, J.C., and MacDONALD, G.M. 1986. The patterns of post-glacial spread of white spruce. Journal of Biogeography 13:527-540.

ROBINSON, A.L., VITT, D.H., and TIMONEY, K.P. 1989. Patterns of bryophyte and lichen distribution in relation to latitudinal and edaphic gradients in the Canadian forest-tundra. Nova Hedwigia 49(1-2):25-48.

SACHS, V.N., and STRELKOV, S.A. 1960. Mesozoic and Cenozoic of the Soviet Arctic. In: Rasch, G.O., ed. Geology of the Arctic. Vol. 1. Toronto: University of Toronto Press. 48-67. 
SAMPSON, R.J. 1978. Surface II graphics system. Kansas Geological Survey, Lawrence, Kansas. Revised edition.

SHILTS, W.W. 1980. Geochemical profile of till from Longlac, Ontario to Somerset Island. CIM Bulletin 73(822):85-94.

TIKHOMIROV, B.A. 1970. Forest limits as the most important biogeographical boundary in the north. In: Ecology of the Subarctic Regions. Proceedings of the Helsinki Symposium, 25 July-3 August 1966. Paris: UNESCO. 35-40.

TIMONEY, K.P., and WEIN, R.W. 1991. The areal pattern of burned tree vegetation in the subarctic region of northwestern Canada. Arctic 44(3):223-230.

TIMONEY, K.P., LA ROI, G.H., ZOLTAI, S.C., and ROBINSON, A.L. 1992. The high subarctic forest-tundra of northwestern Canada: Position, width, and vegetation gradients in relation to climate. Arctic 45(1):1-9.

TIMONEY, K.P., LA ROI, G.H., ZOLTAI, S.C., and ROBINSON, A.L. 1993a. Vegetation communities and plant distributions and their relationships with parent materials in the forest-tundra of northwestern Canada. Ecography 16:174-188.
TIMONEY, K.P., LA ROI, G.H., and DALE, M.R.T. 1993 b. Subarctic forest-tundra vegetation gradients: The sigmoid wave hypothesis. Journal of Vegetation Science 4:387-394.

VAN CLEVE, K., OLIVER, L., SCHLENTNER, R., VIERECK, L.A., and DYRNESS, C.T. 1983. Productivity and nutrient cycling in taiga forest ecosystems. Canadian Journal of Forest Research 13(5):747-766.

VELICHKO, A.A., ed. 1984. Late quaternary environments of the Soviet Union. English edition edited by H.E. Wright and C.W. Barnosky. Minneapolis: University of Minnesota Press.

VIERECK, L.A. 1970. Soil temperatures in river bottom stands in interior Alaska. In: Ecology of the subarctic regions. Proceedings of the Helsinki Symposium, 25 July-3 August 1966. Paris: UNESCO. $223-233$.

WALKER, D.A., SHORT, S.K., ANDREWS, J.T., and WEBBER, P.J. 1981. Late Holocene pollen and present day vegetation, Prudhoe Bay and Atigun River, Alaskan North Slope. Arctic and Alpine Research 13(2):153-172.

ZOLTAI, S.C., and JOHNSON, J.D. 1978. Vegetation-soil relationships in the Keewatin District. Ottawa: Canadian Forestry Service. Fisheries and Environment Canada Report AI-25. 